\title{
Upaya menanggulangi hoax melalui literasi media pada anggota Karang Taruna Desa Tandem Hilir I Kecamatan Hamparan Perak
}

\author{
${ }^{1}$ Humaizi ; ${ }^{2}$ Siti Hazzah Nur Ritonga \\ Program Studi Ilmu Komunikasi, FISIP, Universitas Sumatera Utara, Medan, Indonesia \\ Program Studi Ilmu Administrasi Negara, FISIP, Universitas Sumatera Utara, Medan, Indonesia \\ *Corresponding Author \\ J1. Dr. A. Sofian No.1A, Kampus USU, Medan, Sumatera Utara 20222 \\ Email: humaizi fisipusu@yahoo.com
}

$\begin{array}{llll}\text { Received: } & \text { Revised: } & \text { Accepted: } & \text { Published: } \\ \text { 4 August 2019 } & 7 \text { November 2019 } & \text { 18 November 2019 } & \text { 30 November 2019 }\end{array}$

\begin{abstract}
Abstrak
Hoax merupakan informasi yang direkayasa untuk menutupi informasi sebenarnya. Dengan kata lain hoax juga bisa diartikan sebagai upaya pemutarbalikan fakta menggunakan informasi yang seolah-olah meyakinkan tetapi tidak dapat diverifikasi kebenarannya.Salah satu cara menganngulangi hoax adalah dengan literasi media. Berdasarkan info yang diperoleh, remaja anggota karang taruna desa Tandem Hilir I kecamatan Hamparan Perak belum pernah mendapatkan informasi tentang literasi media sehingga kegiatan ini perlu dilakukan. Kegiatan ini berkokasi di desa Tandem Hilir I kecamatan Hamparan Perak kabupaten Deli Serdang Sumatera Utara. Kegiatan inimenggunakan metode ceramah, dan diskusi. Kegiatan ini berjalan dengan lancar dengan peserta berjumlah 50 orang. Secara umum, kegiatan ini membangkitkan kesadaran para peserta bahwa berita hoax dapat membuat kegaduhan, keributan, dan pertikaian. Para peserta juga menyadari bahwa media sosial dapat digunakan untuk kepentingan yang lebih bermanfaat seperti silaturrahmi dan berbagi informasi yang bermanfaat seperti lowongan pekerjaan, dan membuka kesempatan mendapatkan tambahan pendapatan dengan membuka online shop. Peserta kegiatan juga telah memahami bahwa dampak menyebarkan hoax dapat menyeret ke penjara karena adanya UU ITE. Oleh karena itu, para peserta juga sependapat untuk berhati-hati dalam menyebarkan berita, melakukan factchecking, membaca berita secara utuh, dan memperkuat akidah untuk mampu mengontrol diri. Diharapkan setelah kegiatan ini peserta dapat mengaplikasikan dan menyebarluaskan pengetahuan yang mereka peroleh di lingkungan keluarga dan masyarakat.
\end{abstract}

Kata Kunci: literasi; media; berita; hoax

Abstract
Hoax is defined as information that is engineered to cover up the real
information. In other words, it can also be interpreted as an effort to distort
the facts using information that seems convincing but cannot be verified. One


of the ways to overcome this is through media literacy. Based on the information obtained, youth members of the Karang Taruna Tandem Hilir I village of Hamparan Perak sub-district have never received any information about media literacy, so this activity is urgent to be conducted. This activity is located in the village of Tandem Hilir I, Hamparan Perak sub-district, Deli Serdang Regency, North Sumatra. This activity utilizes lecture, and discussion in its application. This activity ran smoothly with 50 participants. In general, this activity aroused the awareness of the participants that hoax news could trigger commotion, and dispute. They also realized that social media could be used for more useful purposes such as friendship and sharing useful information such as job vacancies, and opening up opportunities for additional income by opening an online shop. They also understood that the impact of spreading hoaxes could lead them to prison because of the ITE law. Therefore, they also agreed to be careful in spreading the news, doing factchecking, reading the whole news, and strengthening the faith to be able to control themselves. It is expected that after this activity, the participants will be able to apply and disseminate the knowledge they have gained in the family and community.

Keywords: literacy; media; news; hoax

\section{PENDAHULUAN}

Dewasa ini, proliferasi teknologi informasi secara signifikan mempengaruhi sebagian besar kehidupan manusia (Komlayut, 2017). Perkembangan media tidak bisa dipisahkan dari perkembangan teknologi informasi. Secara umum, media dapat dibagi menjadi 3 yaitu media cetak, elektronik, dan media baru (new media) (Humaizi, 2018). Media baru (new media) tidak hanya mempercepat penyebaran informasi melalui media berteknologi canggih namun juga memungkinkan khalayak mengembangkan bisnis (Humaizi, 2019). Selain itu, sistem komunikasi telepon pintar atau smartphone yang memungkinkan manusia untuk selalu terhubung dengan alat komunikasi tersebut tanpa harus dipusingkan dengan masalah kabel atau harus selalu duduk di depan komputer ketika akan mengakses sebuah situs internet(Alif, Triartanto, Hardian, Kurniawan, \& Suriyanto, 2018).

Media sosial muncul sebagai bagian dari media baru mendapatkan tempat di hati masyarakat dengan berbagai fasilitas yang ada. Facebook, Instagram, dan Twitter merupakan media sosial yang tidak asing di telinga masyarakat. Bahkan, kita dapat menemukan seseorang yang bisa memiliki dua sampai tiga akun sosial media yang sama. Media sosial mengijinkan kita untuk dapat bertukar informasi dengan semua orang yang merupakan sesama pengguna media tersebut. Menurut (Rahadi, 2017a), media sosial merupakan sarana yang efektif dan efisien sekaligus menjembatani transisi dari masyarakat tradisional menuju masyarakat yang lebih moderen. Berdasarkan data statitistik, jumlah pengguna Internet di Indonesia telah mencapai 132,7 juta orang dari 256,2 juta orang populasi Indonesia (Kurnia \& Astuti, 2017). Lebih lanjut, berdasarkan survei yang dilakukan oleh (APJII, 2016), jenis konten yang paling banyak diakses oleh pengguna internet di Indonesia adalah media sosial mengalahkan penggunaan untuk hiburan, berita, pendidikan. Namun, terkadang media sosial juga dapat digunakan untuk tujuan yang negative seperti penipuan, dan lain-lain.

Hoax berkembang dengan sangat cepat seiring dengan popularitas media sosial. Berita hoax ibarat kereta cepat sangat mudah tersebar hanya dalam hitungan detik.Berbagai macam fasilitas yang disediakan di sosial media menjadi salah satu alat memudahkan menyebarkan berita hoax seperti fasilitas share di Facebook, retweet di Twitter, dan repost di Instagram. Hal itu terjadi seiringdengan meningkatnya pengguna internet di Indonesia (Alif et al., 2018). Saat 
ini, pemberitaan bohong atau palsu (hoax) menjadi fokus perhatian terutama di media sosial (Juliswara, 2017). Peluberan informasi mempersulit khalayak untuk memilih dan membedakan mana informasi yang valid danmana yang palsu (Gumilar, Adiprasetio, \& Maharani, 2017). Lebih jauh lagi, informasi palsu ini menjadi bagian dari konflik sehingga masing-masing mengklaim informasi yang disampaikan oleh kelompoknya adalah yang benar sedangkan lawannya menyampaikan informasi palsu. Hoax sendiri bukanlah barang baru dan sudah ada sejak masa lalu (Manfra \& Holmes, 2018). Hoax merupakan informasi yang direkayasa sedemikian rupa untuk menutupi informasi sebenarnya. Dengan kata lain hoax juga bisa diartikan sebagai upaya penutarbalikan fakta menggunakan informasi yang seolah-olah meyakinkan tetapi tidak dapat diverifikasi kebenarannya. Hoax juga bisa diartikan sebagai tindakan mengaburkan informasi yang sebenarnya, dengan cara membanjiri suatu media dengan pesan yang salah agar bisa menutupi pesan yang benar. Tujuan dari hoax yang disengaja adalah membuat masyarakat merasa tidak aman, tidak nyaman, dan kebingungan. Dalam kebingungan, masyarakat akan mengambil keputusan yang lemah, tidak meyakinkan, dan bahkan salah (Gumilar et al., 2017). Sebagai kesimpulan, hoax merupakan berita yang tidak benar yang dapat merugikan dan menyesatkan banyak pihak.

Desa Tandem Hilir I secara administratif berada di wilayah kecamatan Hamparan Perak kabupaten Deli Serdang dengan luas wilayah $20.63 \mathrm{~km}^{2}$. Desa ini memiliki 11 Dusun dengan kategori Desa berkembang. Desa ini dipimpin oleh Kepala Desa, yaitu bapak Herianto dan Sekretaris Desa, yaitu bapak Zepriansyah. Jumlah penduduk desa Tandem Hilir I pada tahun 2016 berjumlah 13.115 jiwa (Laki-Laki: 6635, \& Perempuan: 6480) (BPS kabupaten Deli Serdang, 2017). Jumlah penduduk yang masuk kategori produktif berjumlah 8626 orang dengan jumlah 3127 rumah tangga. Mayoritas penduduk memiliki pekerjaan sebagai petani dan pegawai perkebunan PT Perkebunan Nusantara II Tanjungmorawa.

Desa Tandem Hilir I juga memiliki karang taruna yang dibentuk tahun 2018 dengan jumlah anggota 50 orang. Berdasarkan hasil observasi dan wawancara yang dilakukan oleh tim pelaksana program pengabdian kepada masyarakat dengan ketua karang taruna, terdapat berbagai macam permasalahan dalam menggunakan sosial media seperti:

1. Asal share berita hoax terutama akhir-akhir ini yang berkaitan dengan isu sosial politik. Mereka membagi berita tersebut terkadang tanpa membaca terlebih dahulu, memahami, dan melakukan cross-check apakah yang informasi dalam bentuk teks atau gambar tersebut benar.

2. Kurangnya pemahaman mengenai dampak hukum yang dapat ditimbulkan dari penyebaran berita hoax.

Dari hasil simpulan wawancara di atas, persoalan utama yang dialami mitra adalah rendahnya pengetahuan literasi media (khusunya penggunaan media sosial) dan membedakan mana berita benar dan berita palsu (hoax). Hoax didefinisikan sebagai usaha untuk menipu atau mengakali pembaca/pendengarnya untuk mempercayai sesuatu, padahal sang pencipta berita palsu tersebut tahu bahwa berita tersebut adalah palsu (Rahadi, 2017b). Selanjutnya, hal ini bertujuan untuk membuat dan menggiring opini publik, serta membentuk persepsi publik serta menguji kecermatan pengguna internet (Suyanto et al., 2018). Selanjutnya, remaja karang taruna desa Tandem Hilir I juga belum pernah mendapatkan sosialisasi tentang literasi media. Oleh karena itu, tim memandang perlu untuk membangun kompetensi remaja dalam menghadapi luapan banjir hoax melalui literasi mediasehingga nantinya para remaja anggota karang taruna akan menjadi cerdas dan bijak dalam menggunakan media sosial khususnya dalam menanggulangi penyebaran berita hoax yang ada di masyarakat.

Literasi media didefinisikan sebagai upaya orang yang terorganisir untuk mengembangkan danmempraktikkan pengetahuan dan keterampilan menggunakan media (RobbGrieco, 2014). Silverblast dalam Alif et al. (2018) menjelaskan lima elemen Literasi 
Media, yaitu 1) Kesadaran akan dampak media massa pada individu dan masyarakat, 2) pemahaman terhadapproses komunikasi massa, 3) Pengembangan strategi untuk menganalisis danmendiskusikan pesan media, 4) Kesadaran isi media sebagai teks yang memberikan masukan bagi budaya kontemporer dan diri kita. 5) Pengolahan rasa senang kepadamedia, pemahaman, dan penghargaan akan isi media.

Literasi media dapat dilakukan dengan berbagai cara. Masyarakat sudah harus diperkenalkan perihal dasar-dasar kecukupan informasi, konsekuensi-konsekuensi terkait persebaran informasi, kesadaran akan bentuk-bentuk teknologi informasi yang dapat memengaruhi mereka, hingga pengetahuan metodis bagaimana mengecek atau memverifikasi yang akan mereka konsumsi(Gumilar et al., 2017). Namun, tidak kalah penting diperlukan pertukaran informasi dan diskusi-diskusiterkait hoax sehingga dapat terbangun komunitas yang memiliki ketahanan terhadap hoax.Pelatihan literasi media ini juga akan menjadi solusi pencegahan dampak negatif, baik itu dampak sosial dan hukum yang timbul dari penyebaran hoax.

\section{METODE}

Dalam kegiatan pengabdian ini, tim menerapkan pendekatan yang berbeda seperti metode ceramah, dan diskusi, yang disesuaikan dengan temuan dilapangan sehingga kegiatan dapat berjalan dengan lancer, serta monev (monitoring dan evaluasi) yang dilakukan setelah kegiatan selesai untuk melihat tingkat pemahaman peserta.

\section{HASIL DAN PEMBAHASAN}

Kegiatan pengabdian dimulai dengan menjalin koordinasi antara tim pengabdian kepada masyarakat dengan ketua karang taruna desa Tandem Hilir I kecamatan Hamparan Perak. Pada saat koordinasi dibicarakan tentang masalah yang terjadi sehingga tercapai kesepakatan untuk melakukan pelatihan literasi media. Kegiatan pengabdian ini dilaksanakan pada tanggal 30 Juni 2019 mulai pukul 10.00-12.00 WIB.Lokasi pelaksanaan program bertempat di Aula Balai Desa Tandem Hilir I Hamparan Perak yang beralamat di Jalan Bahagia No. 6 desa Tandem Hilir I kecamatan Hamparan Perak kabupaten Deli Serdang Sumatera Utara.Kegiatan ini dihadiri oleh Ketua BPD desa Tandem Hilir I mewakili Kepala Desa Tandem Hilir I yang berhalangan hadir, Ketua Karang Taruna Desa Tandem Hilir I, Babinkamtibmas, dan 50 anggota Karang Taruna desa Tandem Hilir I. Secara umum hasil pelaksanaan telah berjalan sebagaimana yang telah direncanakan.

Acara dimulai dengan pembukaan, dilanjutkan dengan kata sambutan oleh ketua BPD, dan ketua Karang Taruna Desa Tandem Hilir I yang menjelaskan latar belakang diadakannya kegiatan ini. Peserta yang hadir dalam kegiatan ini berjumlah 50 orang peserta. Foto peserta kegiatan dapat dilihat pada gambar 1 di bawah ini.

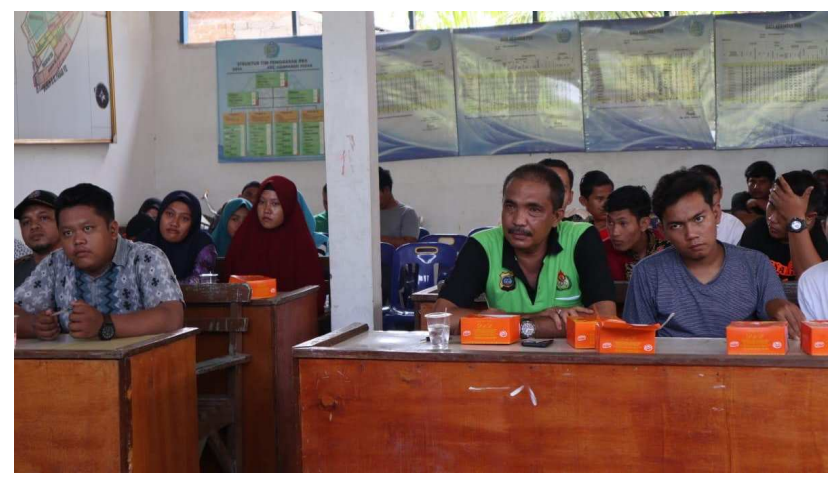

Gambar 1. Peserta pelatihan literasi media 
Materi pertama berisi perkenalan tim pengabdian kepada masyarakat dari Universitas Sumatera Utara, khususnya berasal dari Fakultas Ilmu Sosial dan Ilmu Politik. Tim juga menjelaskan bahwa kegiatan ini merupakan bagian dari salah satu tridarma perguruan tinggi yang harus dilakukan oleh dosen.

Selanjutnya, tim menjelaskan tentang definisi literasi media dan bagaimana menggunakan internet. Tim juga menjelaskan bahwa internet memiliki dampak yang baik dan buruk tergantung bagaimana si pengguna memanfaatkannya. Lebih lanjut, tim menjelaskan bagaimana perkembangan sosial media mulai dari Blackberry Messenger hingga ke WhatsApp, dari Facebook hingga Snapchat. Tim juga berinteraksi dengan bertanya kepada peserta berapa jumlah sosial media yang mereka punya. Seluruh peserta menjawab mereka memiliki akun sosial media dan ada peserta yang menjawab memiliki 2 bahkan 3 akun untuk satu sosial media. Lalu tim juga bertanya, untuk apa punya akun sosial media sebanyak itu. Salah seorang peserta menjawab untuk bermain game secara online.

Pesatnya perkembangan telepon pintar membuat publik semakin mudah mengakses beragam informasi dan berita hanya dalam genggaman tangan. Namun imbasnya informasi palsu ikut tersebar dengan mudah yang bagi sejumlah orang malah diyakini sebagai kebenaran (Alif et al., 2018), padahal informasi tersebut merupakan informasi palsu (hoax). Tim penyaji lantas bertanya kepada peserta apakah pernah menggunakan fiitur share di Facebook. Sebagian besar peserta menjawab sudah dan yang mereka share adalah berita.

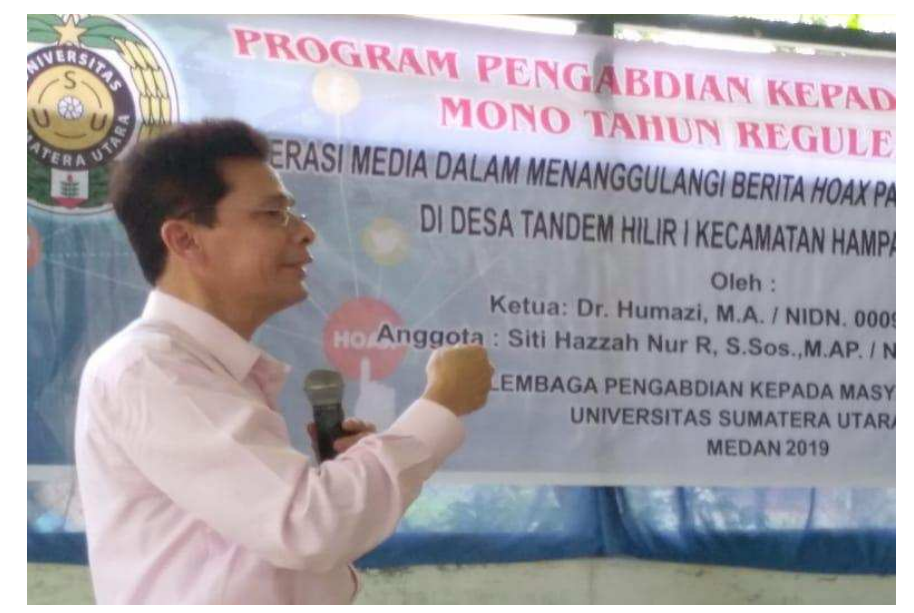

Gambar 2. Pemateri literasi media

Tim penyaji juga menjelaskan apa itu hoax dan mengapa menyebarkan hoax bisa berbahaya. Tim melakukan pemutaran video yang berkaitan dengan hoax dan memberikan contoh berita-berita yang mengandung hoax dan resiko hukum akibat dari perbuatan tersebut. Muncul pertanyaan dari peserta apakah menyebarkan hoax bisa diseret ke ranah hukum. Tim kemudian menjelaskan perihal UU ITE yang dapat digunakan untuk menjerat para penyebar hoax. Hoax dapat menyebar luas karena adanya producer dan consumer. Hoax juga dapat menjadi komoditi bagi para buzzer. Hoax dapat menimbulkan kegaduhan di masyarakat seperti hoax adanya Tsunami atau pencurian organ dalam manusia. 


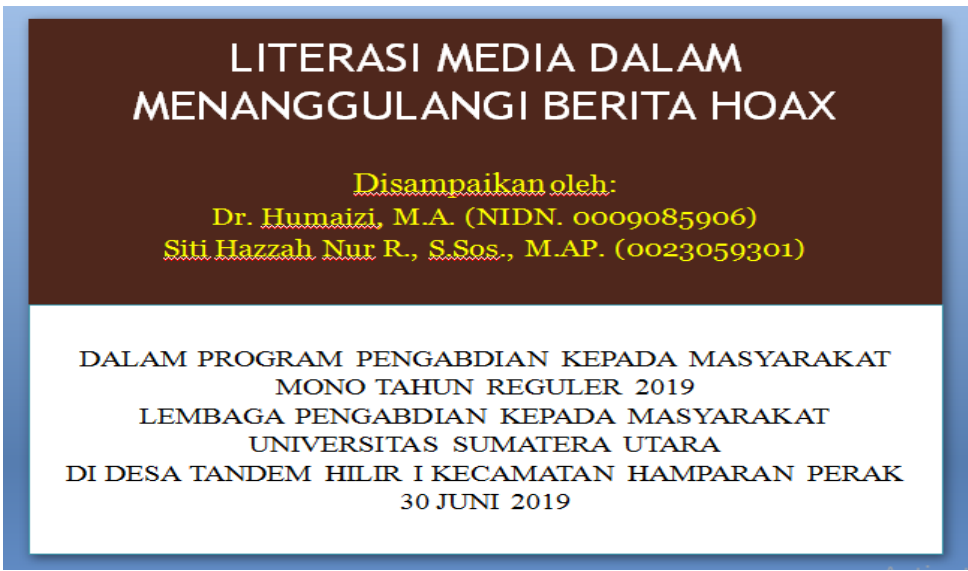

Gambar 3. Bahan presentasi literasi media

Tim penyaji menyampaikan bahwa setiap orang dapat terhindar dari agent penyebar berita hoax dengan melakukan beberapa cara seperti berhati-hati dalam menyebarkan berita yang meragukan atau memancing emosi kita. Berita palsu sering memancing emosi pengguna sosial media sehingga terkadang hanya membaca judul langsung dibagikan tanpa membaca berita secara utuh. Selanjutnya, pengguna sosial media dapat melakukan fact-checking dengan membandingkan dengan berita lain atau mengunjungi situs lain yang sudah terkenal. Selanjutnya, pengguna juga perlumemperkuat akidah untuk mampu mengontrol diri.

Kegiatan ini dilanjutkan dengan sesi tanya jawab oleh peserta. Antusiasme peserta dalam kegiatan ini terlihat dalam sesi diskusi dan tanya jawab yang dilakukan. Tim juga memotivasi para peserta kegiatan untuk cerdas dalam menggunakan sosial media. Penyaji menunjukkan video orang yang sukses memaksimalkan sosial media yang dimiliki sebagai peluang bisnis, dan kembali mengingatkan peserta dengan orang yang telah menyebarkan berita hoax dan berujung masuk penjara. Para peserta kegiatan ini berkomitmen untuk menjadi pelopor anti hoax dan menggunakan media sosial dengan tujuan yang lebih bermanfaat seperti bisnis online atau share tentang lowongan pekerjaan.Tak lupa, sebelum menutup pelatihan tim kembali menanyakan beberapa hal untuk menguji pemahaman peserta tentang materi yang telah disampaikan seperti bagaimana cara menghindari hoax atau langkah preventif yang harus dilakukan dalam menangkal berita hoax. Salah seorang peserta, Iwan, mengatakan bahwa ihoax bisa ditangkal dengan meng-cross-check berita sebelum dibagikan dan tidak hanya membaca judul atau headline berita saja. Kegiatan ditutup dengan sesi foto bersama dan deklarasi remaja karang taruna desa Tandem Hilir I anti hoax.

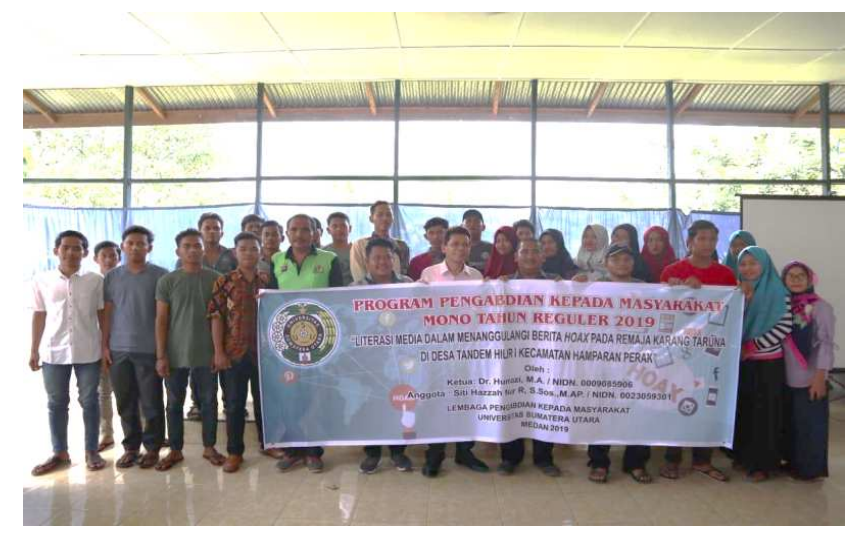

Gambar 4. Foto bersama antara tim dan peserta 


\section{KESIMPULAN DAN SARAN}

Berdasarkan kegiatan yang telah dilakukan, kesimpulan yang dapat ditarik adalah bahwa peserta kegiatan pengabdian memperlihatkan kesadaran mereka bahwa berita hoax dapat membuat kegaduhan, keributan, dan pertikaian. Para peserta juga menyadari bahwa media sosial dapat digunakan untuk kepentingan yang lebih bermanfaat seperti silaturrahmi dan berbagi informasi yang bermanfaat seperti lowongan pekerjaan, dan membuka kesempatan mendapatkan tambahan pendapatan dengan membuka online shop. Peserta kegiatan juga telah memahami bahwa dampak menyebarkan hoax dapat menyeret ke penjara karena adanya UU ITE. Oleh karena itu, mereka juga sependapat untuk berhati-hati dalam menyebarkan berita, melakukan fact-checking, membaca berita secara utuh, dan memperkuat akidah untuk mampu mengontrol diri. Di akhir kegiatan, peserta juga siap menjadi pelopor gerakan anti hoax dan cerdas bersosial media di lingkungan mereka.

Berdasarkan hasil kesimpulan di atas, beberapa saran yang dapat diberikan adalah:

1. Aparat penegak hukum perlu untuk mensosialiasasikan tentang aturan hukum (UU ITE) untuk meningkatkan kesadaran dan sikap mawas diri dalam diri masyarakat.

2. Universitas Sumatera Utara melalui lembaga pengabdian kepada masyarakat dapat melakukan kegiatan seperti ini di daerah dan subjek yang lain seperti di sekolah atau di kelompok-kelompok masyarakat lain. Kegiatan ini perlu dilakukan secara rutin untuk mengedukasi masyarakat di tengah era digital saat ini.

\section{UCAPAN TERIMA KASIH}

Kegiatan pengabdian kepada masyarakat ini dapat terlaksana atas bantuan berbagai pihak. Oleh karena itu, tim pengabdian kepada masyarakat mengucapkan rasa terima kasih yang tulus ikhlas kepada:

1. Rektor Universitas Sumatera Utara.

2. Dekan dan Wakil Dekan III Fakultas Ilmu Sosial dan Ilmu Politik Universitas Sumatera Utara.

3. Lembaga Pengabdian Kepada Masyarakat Universitas Sumatera Utara yang telah memberikan bantuan sumber dana Non PNBP USU TA. 2019.

4. Perangkat Desa Tandem Hilir I Kecamatan Hamparan Perak.

5. Karang Taruna Desa Tandem Hilir I Kecamatan Hamparan Perak.

6. Babinkamtibmas Desa Tandem Hilir I Kecamatan Hamparan Perak.

\section{DAFTAR PUSTAKA}

Alif, M. A., Triartanto, A. Y., Hardian, A., Kurniawan, F., \& Suriyanto, A. D. (2018). Literasi Media Dalam Menanggulangi Berita Hoax (Studi Pada Pelajar SMKN 4 Bekasi dan Mahasiswa AKOM BSI, Jakarta). Jurnal Abdimas BSI: Jurnal Pengabdian Masyarakat, 1(3), 416-423.

APJII. (2016). Penetrasi dan Perilaku Pengguna Internet 2016. Jakarta: APJII.

Gumilar, G., Adiprasetio, J., \& Maharani, N. (2017). Literasi Media: Cerdas Menggunakan Media Sosial dalam Menanggulangi Berita Palsu (Hoax) oleh Siswa SMA. Jurnal Pengabdian Kepada Masyarakat, 1(1), 35-40.

Humaizi. (2018). The Correlation between Broadcasting Spill-Over of Malaysian Television and Radio on Islamic Religious Knowledge of Community Members in East Aceh. Jurnal 
Komunikasi, Malaysian Journal of Communication, 34(1), 202-217. https://doi.org/10.17576/JKMJC-2018-3401-12

Humaizi. (2019). Teori Komunikasi Massa: Uses and Gratifications. Medan: USU Press.

Juliswara, V. (2017). Mengembangkan Model Literasi Media yang Berkebhinnekaan dalam Menganalisis Informasi Berita Palsu (Hoax) di Media Sosial. Jurnal Pemikiran Sosiologi, 4(2), 142. https://doi.org/10.22146/jps.v4i2.28586

Komlayut, S. (2017). Assessing Digital Literacy Skills Using a Self-Administered Questionnaire. 6(3), 74-85.

Kurnia, N., \& Astuti, S. I. (2017). Peta Gerakan Literasi Digital di Indonesia: Studi tentang Pelaku, Ragam Kegiatan, Kelompok Sasaran dan Mitra. Informasi: Kajian Ilmu Komunikasi, 47(2), 149-166.

Manfra, M. M., \& Holmes, C. (2018). Media Literacy and Fake News in the Social Studies. Social Education, 82(2), 91-95.

Rahadi, D. R. (2017). Perilaku Pengguna dan Informasi Hoax di Media Sosial. Jurnal Manajemen dan Kewirausahaan, 5(1), 58-70. https://doi.org/10.26905/jmdk.v5i1.1342

RobbGrieco, M. (2014). Why History Matters for Media Literacy Education. Journal of Media Literacy Education, 6(2), 3-22. https://doi.org/10.23860/JMLE-2016-06-02-2

Suyanto, T., Prasetyo, K., Isbandono, P., Zain, I. M., Purba, P., \& Gamaputra, G. (2018). Persepsi mahasiswa terhadap kemunculan berita bohong di media sosial. Jurnal Civics: Media Kajian Kewarganegaraan, 15(1), 52-61. 